\title{
ECOAL Project-Delivering Solutions for Integrated Monitoring of Coal-Related Fires Supported on Optical Fiber Sensing Technology
}

\author{
Joana Ribeiro $^{1,2}$ (D), Duarte Viveiros ${ }^{3,4}$ (D), João Ferreira ${ }^{3}{ }^{(D)}$, Alexia Lopez-Gil ${ }^{5}$,
} Alejandro Dominguez-Lopez ${ }^{5}$, Hugo F. Martins ${ }^{5}$, Rosa Perez-Herrera ${ }^{6}$, Aitor Lopez-Aldaba ${ }^{6}$, Lia Duarte 1,2 (D), Ana Pinto ${ }^{6,7}$, Sonia Martin-Lopez ${ }^{5}$, Hardy Baierl ${ }^{8}$, Raphael Jamier ${ }^{8}$, Sébastien Rougier ${ }^{8}$, Jean-Louis Auguste ${ }^{8}$, Ana Cláudia Teodoro ${ }^{1,2}$, José Alberto Gonçalves ${ }^{1,9}$, Oscar Esteban ${ }^{5}$, José Luís Santos ${ }^{3,4}$, Philippe Roy ${ }^{9}$, Manuel Lopez-Amo ${ }^{6}$, Miguel Gonzalez-Herraez ${ }^{5}$, José Manuel Baptista ${ }^{3,10}$ (iD and Deolinda Flores ${ }^{1,2, *}$

1 Department of Geosciences, Environment and Spatial Planning, Faculty of Sciences, University of Porto, 4169-007 Porto, Portugal; joanaribeiro@fc.up.pt (J.R.); liaduarte@fc.up.pt (L.D.); amteodor@fc.up.pt (A.C.T.); miguel.gonzalezh@uah.es (J.A.G.)

2 Institute of Earth Sciences, Pole of University of Porto, 4169-007 Porto, Portugal

3 Center for Applied Photonics, INESC TEC, 4169-007 Porto, Portugal; carlos.d.viveiros@inescporto.pt (D.V.); joao.ferreira@inescporto.pt (J.F.); josantos@fc.up.pt (J.L.S.); jmb@inescporto.pt (J.M.B.)

4 Department of Physics and Astronomy, Faculty of Science at University of Porto, 4169-007 Porto, Portugal

5 Departamento de Electrónica, Universidad de Alcalá, 28801 Alcalá de Henares, Spain; alexia.lopez@uah.es (A.L.-G.); alejandro.dominguezl@uah.es (A.D.-L.); hugo.martins@focustech.eu (H.F.M.); sonia.martin@uah.es (S.M.-L.); oscar@uah.es (O.E.); miguel.gonzalezh@uah.es (M.G.-H.)

6 Department of Ingeniería Eléctrica y Electrónica, Universidad Pública de Navarra, 31006 Pamplona, Spain; rosa.perez@unavarra.es (R.P.-H.); aitor.lopez@unavarra.es (A.L.-A.); ana.pinto@inescbrasil.org.br (A.P.); mla@unavarra.es (M.L.-A.)

7 Federal University of Santa Catarina, Centro de Engenharia da Mobilidade (CEM), Florianopolis 89.218-035, Brazil

8 CNRS, XLIM-Département Photonique-Fibre, Faculté des Sciences et Techniques, 87060 Limoges, France; hardy.baierl@ipht-jena.de (H.B.); raphael.jamier@xlim.fr (R.J.); sebastien.rougier@xlim.fr (S.R.); jean-louis.auguste@xlim.fr (J.-L.A.); philippe.roy@xlim.fr (P.L.)

9 Interdisciplinary Centre of Marine and Environmental Research, University of Porto, 4450-208 Matosinhos, Portugal

10 Faculdade de Ciências Exatas e da Engenharia, Universidade da Madeira, 9020-105 Funchal, Portugal

* Correspondence: dflores@fc.up.pt; Tel.: +351-220-402-490

Received: 31 July 2017; Accepted: 13 September 2017; Published: 16 September 2017

\begin{abstract}
The combustion of coal wastes resulting from mining is of particular environmental concern, and the importance of proper management involving real-time assessment of their status and identification of probable evolution scenarios is recognized. Continuous monitoring of the combustion temperature and emission levels of certain gases allows for the possibility of planning corrective actions to minimize their negative impact on the surroundings. Optical fiber technology is well suited to this purpose and here we describe the main attributes and results obtained from a fiber optic sensing system projected to gather data on distributed temperature and gas emissions in these harsh environments.
\end{abstract}

Keywords: coal mining; coal waste deposits; spontaneous coal combustion; optical fiber sensing; temperature measurement; gas detection; environmental impact 


\section{The ECOAL Project}

The scientific research project "ECOAL-Ecological Management of Coal Waste Piles in Combustion" (2012-2015) was a transnational project consisting of a consortium of five partners from three European countries (Portugal, Spain, and France), with representatives from academia and research units, combining geological and geosciences expertise with optoelectronic competences and complementary know-how in fiber optic sensing, ranging from fundamentals to system development and field tests. The Portuguese institutions were the Institute for Systems and Computer Engineering of Porto-INESC Porto and the Faculty of Sciences, University of Porto, in Spain the partners were the University of Alcala (Madrid) and Universidad Publica de Navarra (Pamplona), while from France it involved the XLIM UMR CNRS Université de Limoges. This project was supported by the SUDOE-Interreg IV B program, and was designed and planned to contribute to the management of the environmental problems associated to the self-burning coal waste piles, involving continuous assessment of their status and identification of evolution scenarios, looking at the implementation of corrective/preventive actions to minimize the impact of these natural combustion processes.

Several works $([1,2]$ and references therein) reported the application of the fiber optic-based systems for monitoring of ambient conditions in underground coal mines, which have strong implications in safety, productivity, and operation costs. However, the application of fiber optic-based sensing technologies for monitoring of coal-related fires, which cause serious impacts on environment and human health, was never developed.

The ECOAL project was developed aiming the remote, multi-point, and continuous monitoring of gas emissions and combustion temperature in a self-burning coal waste pile using advanced optical fiber sensing technology. The combustion of coal wastes resulting from mining is of particular environmental concern, so the importance of proper management involving real-time assessment of their status and identification of probable evolution scenarios is recognized. The motivation for the continuous monitoring of combustion temperature and emission levels of certain gases is that it opens up the possibility of planning corrective actions to minimize their negative impact on the surroundings. Optical fiber technology is well suited to this purpose, which is why it was decided to project a fiber optic sensing system to gather data on distributed temperature and gas emissions in these harsh environments.

After the laboratory development of fiber optic-based systems for distributed temperature and gas emission measurements, a prototype was installed in S. Pedro da Cova waste pile, which resulted from coal mining in Douro Coalfield (North of Portugal).

The integration and analysis of the results obtained in the project [3-9] allowed for the study of the dynamics and evolution pathways of the combustion process within the coal waste pile, as well as the identification of potential hazards to the environment and human health. In addition, the acquired knowledge and experience enable system optimization, opening up its widespread application in other self-burning coal waste piles as well as in other similar environments, such as coal storage piles.

\section{Coal-Related Fires-A Geoenvironmental Problem}

Both coal mining and coal consumption have unquestionable benefits for the economic and social segments of many countries, despite their harmful impacts on the environment and human health [10]. The environmental impacts related with coal mining may include alterations in landscape and land use; soil erosion; increased noise generation; production of solid wastes; pollution of the air, surface and groundwater, soils and sediments; land instability, subsidence; coal-related fires; and effects on local biodiversity $[10,11]$.

Coal-related fires are a worldwide phenomenon that has been extensively investigated in recent years [12-16]. These occurrences are also an environmental concern and have recently been studied in Europe [17-21], specifically on the Iberian peninsula [8,22-30]. In this context, coal fires are related to spontaneous combustion or ignition caused by extrinsic factors of coal and coal-rich materials that lead to the self-combustion process over variable periods of time (frequently over decades). The self-heating 
propensity of coal and coal-rich materials due to the oxidation of sulfides promotes the ignition. The investigation of coal-related fires occurring all over the world has been the subject of several studies that focused on the economic losses of coal resources, the environmental impacts associated with the combustion process, and monitoring and fire-fighting possibilities [31].

The self-combustion of coal may occur in unmined coal seams, during coal mining operations, handling, and transportation, storage and in coal mining waste deposits, being responsible for significant losses of natural energy resources [10]. The geological materials most frequently involved in coal-related fires are the coal in seams and the host rocks, the whole coal in storage piles, and the rejected and overburden material resulted from coal mining and beneficiation (containing a mixture of fragments of coal and host rocks). The self-combustion process of coal and coal-rich materials is responsible for the mobilization of large quantities of pollutants caused by the volatilization of elements present in coal and associated mineral matter. The environmental impacts caused by coal-related fires includes the emission of harmful gases and particulate matter into the atmosphere, mobilization and leaching of hazardous elements into soil and water, and the formation of solid byproducts (coal fire gas minerals) [10,32-35]. As a consequence, the pollution of air, soils, sediments, surface and groundwater, and effects on human health and biodiversity occur. The uncontrolled release of these pollutants, namely greenhouse gases, volatile organic compounds, particulate matter, and toxic elements, represents a risk to the environment and to human health. The risk is even more severe when the process occurs near populated areas, since some of the pollutants are known to be toxic and human carcinogens [33].

The comprehensive characterization of the affected geological materials, including petrological, mineralogical, and geochemical studies, permits the evaluation of factors responsible for the self-heating, spontaneous combustion, and self-combustion processes, the identification of the changes induced in the affected materials, and the gathering of insights about the associated potential environmental impacts, allowing for a definition of timely corrective measures to minimize the negative impacts. The characterization of the self-combustion byproducts (gases and coal fire gas minerals) is also essential to address the environmental issues and effects on human health and ecosystems.

\section{Case Study}

The Douro Coalfield (NW of Portugal) represents the most important coal-bearing deposit in Portugal (Upper Pennsylvanian), with a NW-SE alignment, a variable width (30-250 m) and approximately $53 \mathrm{~km}$ in length [36]. The Douro Coalfield sedimentary record corresponds to an intramontane basin with alluvial-palustrine/lacustrine-fluvial and deltaic deposits containing coal seams [36].

The coal-bearing deposits of anthracite A [37] from the Douro Coalfield were exploited for many years (1795-1994) in two principal centers of mining activity (the S. Pedro da Cova and Pejão mining areas) and in several small mines dispersed in the Douro Coalfield area [38]. The exploited coal was the main fuel supply used for power generation in the Tapada do Outeiro thermal power plant between 1959 and 1997, although it was also used for household, cement, and metallurgical industry [38]. Both coal mining and coal consumption contributed significantly to the economic and energy sectors of Portugal, as well as to the socioeconomic and cultural sectors of the region.

Despite the importance of mining in the Douro Coalfield, its exploitation and consumption inevitably impacted the environment. The rejects and overburdened material that resulted from the exploitation of the Douro Coalfield were discarded in at least 28 waste piles placed over the old mine sites and adjacent areas, representing a significant environmental impact associated with the mining activities in the region [24]. Three of these waste piles, namely, S. Pedro da Cova, Midões, and Lomba, started burning in 2005 after ignition caused by forest fires, further adding to environmental concerns [22].

The S. Pedro da Cova waste pile is still undergoing a self-combustion process and is located close to the oldest center of mining activities in S. Pedro da Cova and near to a population center 
and social infrastructure. This waste pile has an elongated form, occupying an area of approximately $28,000 \mathrm{~m}^{2}$, with the burning process occurring only along the south slope. Previous work deals with the comprehensive characterization of the materials that constitute the S. Pedro da Cova waste pile as well as with the identification of combustion byproducts (gases emitted from vents and coal fire gas minerals) [22-28]. The sampling for previous studies included the collection of solid waste material from burning or already burnt zones and from unburned zones of the waste deposit, neoformed minerals found in the surface of the deposit (coal fire gas minerals), and gaseous emissions. Figure 1 shows some images of the S. Pedro da Cova waste pile and some particular aspects related with the combustion process, such as the gaseous emissions and neoformed minerals. The methodologies applied for comprehensive characterization of the sampled materials from S. Pedro da Cova waste pile included petrographic, mineralogical, and geochemical studies.
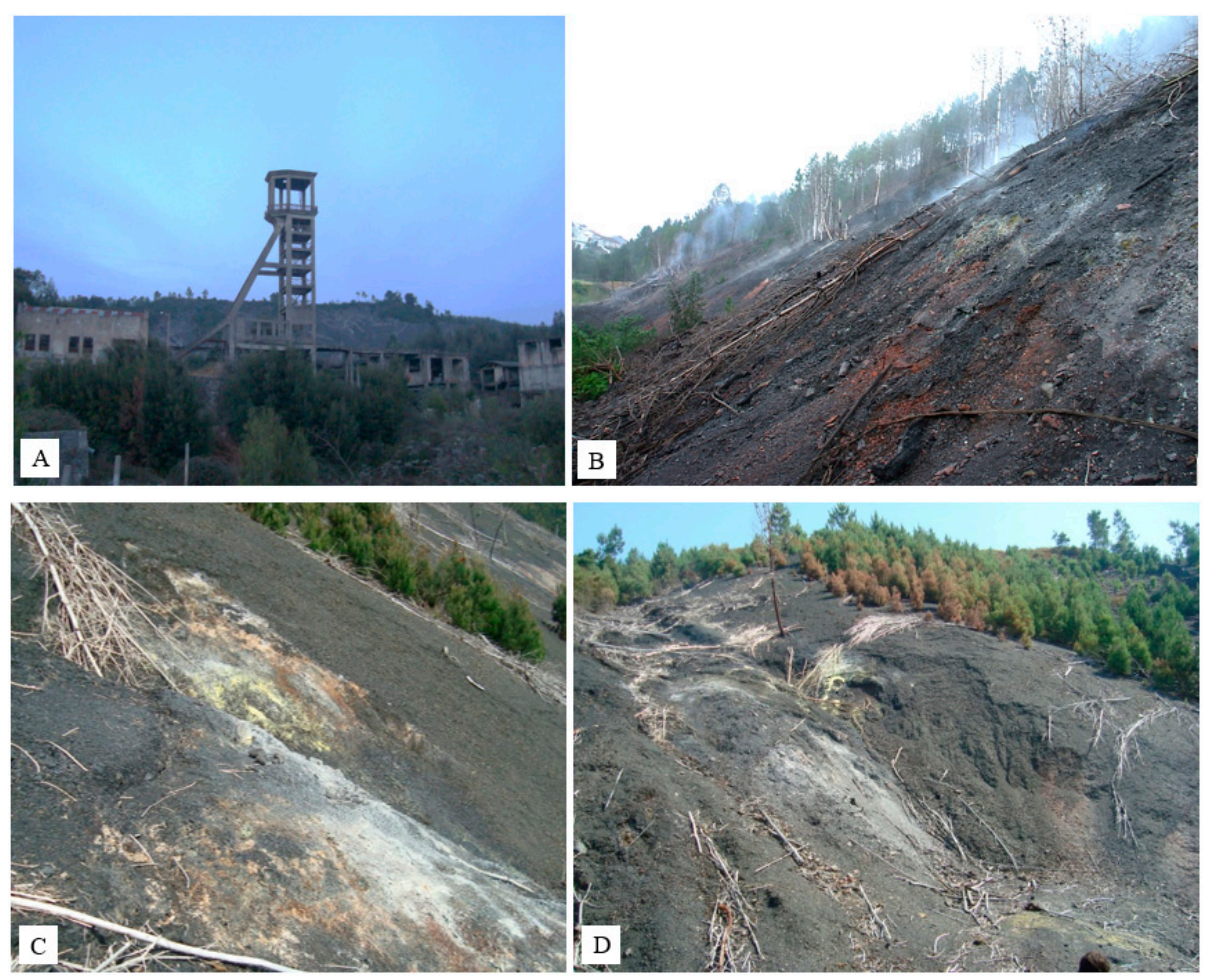

Figure 1. (A) Old mining infrastructures and, behind, the S. Pedro da Cova waste pile; (B) general view of the burning slope of S. Pedro da Cova waste pile where the gaseous emissions and burnt vegetation are visible; (C) detailed view of the burning slope showing the neoformed minerals in the surface of the slope (yellow—sulfur; white—salammoniac); (D) selected area for the prototype installation.

The petrographic observations of waste materials show that organic and inorganic matter is affected by weathering processes as well as by the combustion process. Figure 2 shows some petrographic aspects that are evidence of the effects caused by the combustion process. The thermally affected waste material shows strong petrographic changes such as development of dark reaction rims (Figure 2A), devolatilization vacuoles, cracks, and reduced anisotropy in organic particles, development of pyrolytic carbon (Figure 2B) and char structures, oxidation of sulfides (e.g., pyrite), and formation of iron oxides (Figure 2C) [22].

The mineralogical phases identified in the burning or burnt waste material (e.g., mullite, cristobalite, and hematite) demonstrated that combustion temperature reached at least $1000{ }^{\circ} \mathrm{C}$, and may have reached temperatures of $1500{ }^{\circ} \mathrm{C}$. The magnetic parameters demonstrated a significant magnetic enhancement, which is attributed to the combustion process that was responsible for the formation of iron oxides [28]. 
The comparison of geochemical composition of the burnt/burning waste material and the unburned material allow for the identification of enhancement or depletion behavior of elements due to the combustion process [22]. The enrichment of elements may result from the elements' concentration due to the volatilization of other elements and organic matter consumption during the combustion process. The depletion of elements may be associated with their volatilization during combustion. However, other reasons for enrichment or depletion, such as the element's mode of occurrence, weathering, and/or leaching, should be considered. A cluster analysis considering data about the chemical composition of samples reveals a clear geochemical differentiation between burnt/burning waste material and unburned material [22].
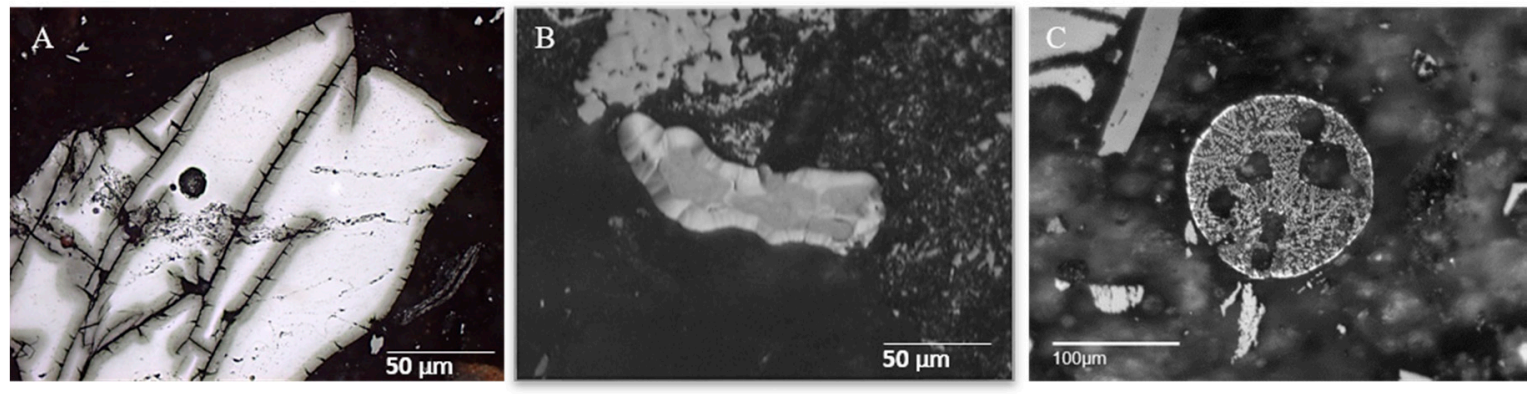

Figure 2. (A) Organic particle with cracks and dark reaction rims; (B) pyrolytic carbon; (C) iron oxide sphere.

The chemical composition of leachates obtained from S. Pedro da Cova waste material presents a higher concentration of elements in burning/burnt material when compared with unburned material, indicating that the combustion process affected the elements' mode of occurrence and their availability to be leached [24]. The higher element concentrations in leachates from burning/burnt waste material, the depletion of low-molecular-weight polycyclic aromatic hydrocarbons concentrations, and a greater abundance of high-molecular-weight polycyclic aromatic hydrocarbons from the unburned coal waste material are attributed to the geochemical changes induced by the burning process [24,25].

The combustion process in the S. Pedro da Cova waste pile gave rise to atmospheric emissions of high concentrations of a wide variety of volatile organic compounds, including BTEX compounds (benzene, toluene, ethylbenzene, and xylene) and to the formation of sulfur and salammoniac, which results from the exhalation and condensation of gas by interaction with surface water, atmospheric gases and surrounding rocks [22].

\section{Fiber Sensing Technologies}

Fiber optic sensors have proven themselves in harsh environments, presenting high sensitivity, wide bandwidth, high operation temperature, immunity to electromagnetic interference, lightweight, long life, and multipoint as well as remote measurement capabilities. In view of these characteristics, fiber optic sensing technology was selected for the build-up of the coal waste pile monitoring system, which has two components, one relative to the emission of methane $\left(\mathrm{CH}_{4}\right)$, ammonia $\left(\mathrm{NH}_{3}\right)$, and carbon dioxide $\left(\mathrm{CO}_{2}\right)$ in certain points of the waste pile, and the other associated with distributed temperature measurement.

\subsection{Temperature Measurement with Fiber Bragg Gratings and Microstructured Fibers}

Reliable high-temperature sensors are indispensable in some fields, such as tunnel monitoring, material processing, mine monitoring, structure health monitoring, oil well monitoring, and so on. Traditional electrical high-temperature sensors have some disadvantages, including low reliability, large temperature fluctuations, and danger of accidental fires. Optical fiber Bragg grating (FBG) sensors have numerous advantages over traditional electrical sensors, such as those inherent to fiber 
sensors in general, as well as the fact the measures (in this case temperature) are encoded in an absolute parameter, the optical wavelength [39]. Therefore, FBG sensors are the most appropriate sensors for monitoring applications in the fields mentioned above.

A fiber Bragg grating is a periodic microstructure, typically a few millimeters in length, inscribed in the core of a fiber. It has the ability to reflect certain emission wavelengths and transmit others. The reflection wavelength of the FBG (Fiber Bragg wavelength, $\lambda_{B}$ ) depends on the grating characteristics (period, refractive index modulation amplitude) and is influenced by the ambient conditions such as strain and temperature. This allows the utilization of FBG as a sensor for strain and temperature. In the case of temperature sensing, the Bragg wavelength is a function of the temperature. This temperature dependence results from changes of the refractive index of the fiber as well as from thermal expansion of the glass material. The Bragg wavelength of the structure is given by $\lambda_{B}=2 n_{e f f} \Lambda$, where $n_{\text {eff }}$ is the effective index of refraction of the fiber guided mode and $\Lambda$ is the period of index modulation. For a $\Delta \mathrm{T}$ temperature change the Bragg wavelength variation is given by:

$$
\frac{\Delta \lambda_{B}}{\lambda_{B}}=(\alpha+\zeta) \Delta \mathrm{T}
$$

where $\alpha$ is the coefficient of thermal expansion of the fiber and $\zeta$ is its thermo-optic coefficient (dependence of the index of refraction on temperature).

In the sensing system installed, FBGs were used for point measurements and co-located with the gas sensors for calibration purposes. Looking essentially to technology validation, a second type of temperature sensor was installed, namely an interferometric structure based on a microstructured optical fiber designed and fabricated within the project consortium [40].

\subsection{Temperature Measurement with Brillouin Scattering}

Distributed Brillouin sensing was proposed in the late 1980s as an alternative technique to the classic optical time-domain reflectometry to measure local attenuation along an optical fiber, but as soon it was realized it had many more potentialities for sensing, since Brillouin scattering is intrinsically sensitive to temperature and the deformations experienced by the fiber. Physically, distributed fiber optic sensing is based on the scattering of photons due to density fluctuations in the fiber. When the density fluctuations are dynamic, the scattered photons experience a frequency shift with a magnitude equal to the frequency of the density fluctuations. Through direct proportionality, the frequency shift is representative of the corresponding energy difference between the incident and scattered photons. This energy difference corresponds to the flux of acoustic phonons (sound waves) generated through electrostriction initiated by the strong input light waves entering the fiber, and the resulting scattering process is called Brillouin scattering. Brillouin scattering temperature based systems detect temperature changes by measuring the Brillouin backscattered intensity and its frequency shift as a function of temperature [41].

Although Brillouin scattering yields signals that are approximately $10^{5}$ to $10^{6}$ times weaker than the incident light, they may be enhanced through a process known as Stimulated Brillouin Scattering (SBS). This can be achieved by sending light from two lasers into opposite ends of the sensing fiber. Through modulation of a pulsed laser, its amplification will occur at the expense of the second continuous wave laser. This amplification process allows the fiber sensing length to be significantly increased due to an improved signal-to-noise ratio resulting from nonlinear amplification in the fiber. This approach to Brillouin sensing is known as Brillouin Optical Time-Domain Analysis (BOTDA) and constituted a breakthrough in distributed sensing. Concerning temperature measurement, this technique permitted a measurement length in excess of $100 \mathrm{~km}$ with sub-meter spatial resolution [42].

For distributed temperature measurement of the coal waste pile, Brillouin Optical Time-Domain Analysis was proposed with a single-mode fiber layout extended over the whole area of the waste pile in combustion. Details are presented in Section 5.1. 


\subsection{Optical Sensing for Gas Detection}

Optical gas sensing is mostly associated with the detection of optical absorption by the targeted gas when an optical beam propagates in a region where the gas is present. Several techniques with such a purpose have been developed over the years; the most successful one is the so-called Wavelength Modulation Spectroscopy (WMS). It is a rather sensitive technique for detecting atomic/molecular species, with the advantage that it can be implemented in the near-infrared region by considering optical telecommunications technology [6].

\subsubsection{Wavelength Modulation Spectroscopy (WMS)}

Absorption spectroscopy is based on a unique signature attenuation of spectral intensity caused by the gas to be monitored. It happens when light radiation interacts with molecular species and is represented by the Beer-Lambert Law $[6,43,44]$ :

$$
I_{t}(\lambda)=I_{0}(\lambda) e^{-\alpha(\lambda) L}
$$

where $I_{t}(\lambda)$ and $I_{0}(\lambda)$ are the transmitted and incident light intensity at wavelength $\lambda$ of the laser diode, respectively, and $L$ is the interaction length or path length that the light has to pass through the gas. The absorption coefficient $\alpha(\lambda)$ is $\alpha(\lambda)=C \times \varepsilon(\lambda)$, where $C$ is the gas concentration and $\varepsilon(\lambda)$ the specific absorptivity of the gas $[6,43,44]$. A typical experimental configuration of WMS is composed by a DFB laser diode, which is wavelength-tuneable, a function generator, a gas chamber, a photodetector , and a lock-in amplifier, as illustrated in Figure 3.



Figure 3. Wavelength Modulation Spectroscopy (WMS) basic configuration; (a) laser scan through a single gas absorption line and (b) synchronous detection of first and second harmonic of the laser modulation through a lock-in amplifier.

In this technique, the laser wavelength and intensity are modulated by applying at the laser diode injection current a sinewave signal at a frequency in the order of $\mathrm{kHz}$. A ramp signal is added to sweep the laser frequency across the gas absorption line. The sinusoidal modulation in the operational $\mathrm{kHz}$ range allows the shift of the detection bandwidth to higher frequencies where laser intensity noise is 
reduced. From Figure 3a, the modulated laser light interacts with the absorption line of the target gas and two possible situations may be observed: (i) the modulated frequency is doubled when the laser light is tuned to the center of absorption line; and (ii) the frequency remains unchanged when the laser is tuned out of the center of the absorption line. Therefore, this interaction between the modulated laser light and absorption line of the target gas generates signals at different harmonics of the applied modulation frequency (see Figure 3b).

Gas concentration is typically detected by recovery of the second harmonic (2f) of the laser modulation frequency through a synchronous detection, using a lock-in amplifier. The first and second demodulated harmonics are shown in Figure 3b, where the amplitude of the second harmonic (2f) of the laser modulation frequency is proportional to the gas concentration. The first harmonic (f) is proportional to the first derivative of the gas absorption line and equals zero when the wavelength modulated laser light is centered in the target gas absorption line.

\subsubsection{Gas Sensing System Design}

In the combustion process of coal waste piles, several gases are emitted; for emissions monitoring three were selected, namely ammonia $\left(\mathrm{NH}_{3}\right)$, methane $\left(\mathrm{CH}_{4}\right)$, and carbon dioxide $\left(\mathrm{CO}_{2}\right)$. For the choice of the DFB lasers with emission wavelength in the near-infrared region, it is important to take into account the absorption lines intensity of these gases because in this region the intensity of the absorption lines is reduced compared to the infrared region. Thus, the DFB lasers of the experimental setup work at wavelengths of $1653.72 \mathrm{~nm}$ (for $\mathrm{CH}_{4}$ detection), $1572.0 \mathrm{~nm}$ (for $\mathrm{CO}_{2}$ detection), and $1512.21 \mathrm{~nm}$ (for $\mathrm{NH}_{3}$ detection), where their respective gas absorption response is unique. The experimental setup implemented in the gas sensing units $\left(\mathrm{NH}_{3}, \mathrm{CO}_{2}\right.$, and $\left.\mathrm{CH}_{4}\right)$ using the WMS is shown in Figure 4.

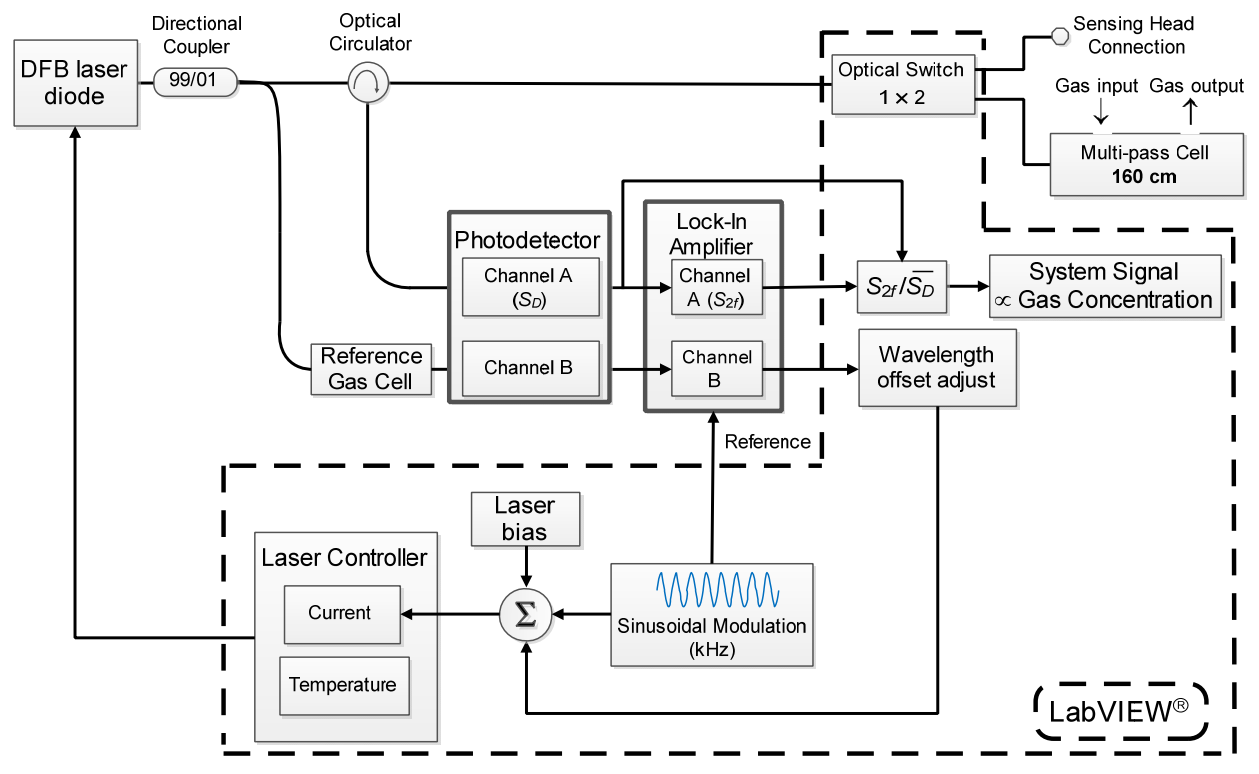

Figure 4. Schematic diagram of the system for gas sensing using WMS.

The experimental setup for gas sensing included two types of sensing heads. One was based on commercially available flow cells (Wavelength References Inc., Corvallis, OR, USA-FC-H(80)-1/8-none-80 cm flowcell with no connectors and 1.8" swagelok fittings for gas inlet/outlet) permitting free light propagation and interaction with the gas along an optical path length of $\sim 160 \mathrm{~cm}$ (the flow cell was operated in reflection), and another relying on microstructured optical fibers with gases diffusing in their hole. Through an optical switch, the system allows us to select the sensing head to be used. 
Three reference gas cells were also used to fine tune the wavelength emission of the DFB lasers to the selected gas absorption line. These cells had a $100 \%$ concentration of each gas with a pressure of $0.263 \mathrm{~atm}$ at room temperature. The optical path length of the $\mathrm{NH}_{3}$ and $\mathrm{CH}_{4}$ cells was $5.5 \mathrm{~cm}$, while it was $80 \mathrm{~cm}$ for the $\mathrm{CO}_{2}$ cell. The control of the gas sensing system presented in Figure 4, as well as acquisition, processing, and data presentation, was performed using a LabVIEW®application (National Instruments, Oeiras, Portugal).

The DFBs laser diodes selected for each gas $\left(\mathrm{NH}_{3}, \mathrm{CO}_{2}\right.$ and $\left.\mathrm{CH}_{4}\right)$ provided $7 \mathrm{~mW}$ at $1512.21 \mathrm{~nm}$ and $1572.0 \mathrm{~nm}$ and $10 \mathrm{~mW}$ at $1653.72 \mathrm{~nm}$ with a specified linewidth $<2 \mathrm{MHz}$. The fiber was spliced to a $99 / 1(\%)$ directional coupler with the $99 \%$ arm sent to the optical switch. The $1 \%$ arm was used as the reference beam passing through the reference $\left(\mathrm{NH}_{3}, \mathrm{CO}_{2}\right.$, and $\left.\mathrm{CH}_{4}\right)$ gas cell.

Figure 5 shows the $\mathrm{NH}_{3}$ gas absorption line for a concentration of 100\% in the 1511.2-1513.6 nm region, a temperature range of $16-27^{\circ} \mathrm{C}$, and over the current range $27-103 \mathrm{~mA}$. As a result, the $\mathrm{NH}_{3}$ absorption line detected by the shift had a center wavelength of $1512.21 \mathrm{~nm}$ and a full width at half maximum (FWHM) of $59 \mathrm{pm}$. For the $\mathrm{CO}_{2}$ and $\mathrm{CH}_{4}$ absorption lines detected by the shift, the center wavelength was found to be $1572 \mathrm{~nm}$ and $1653.72 \mathrm{~nm}$ and the full width at half maximum (FWHM) of $40 \mathrm{pm}$ and $41 \mathrm{pm}$, respectively. The laser wavelength and intensity was modulated by applying a sine wave signal with a frequency of $5 \mathrm{kHz}$. The initial injection DC current (laser bias) and temperature were set in the Laser Controller to $61.3 \mathrm{~mA}$ and $21.6^{\circ} \mathrm{C}$, respectively, in order to tune the emission wavelength DFB laser diode to the desired wavelength of the $\mathrm{NH}_{3}$ absorption line $(1512.21 \mathrm{~nm})$. To tune the emission wavelength DFBs laser diodes to the desired wavelength of the $\mathrm{CO}_{2}$ and $\mathrm{CH}_{4}$ absorption lines (1572.0 $\mathrm{nm}$ and $1653.72 \mathrm{~nm}$ ), the injection DC current and temperature were set in the Laser Controller to $97.8 \mathrm{~mA}$ and $65 \mathrm{~mA}$ and $33.24^{\circ} \mathrm{C}$ and $21.73^{\circ} \mathrm{C}$, respectively.

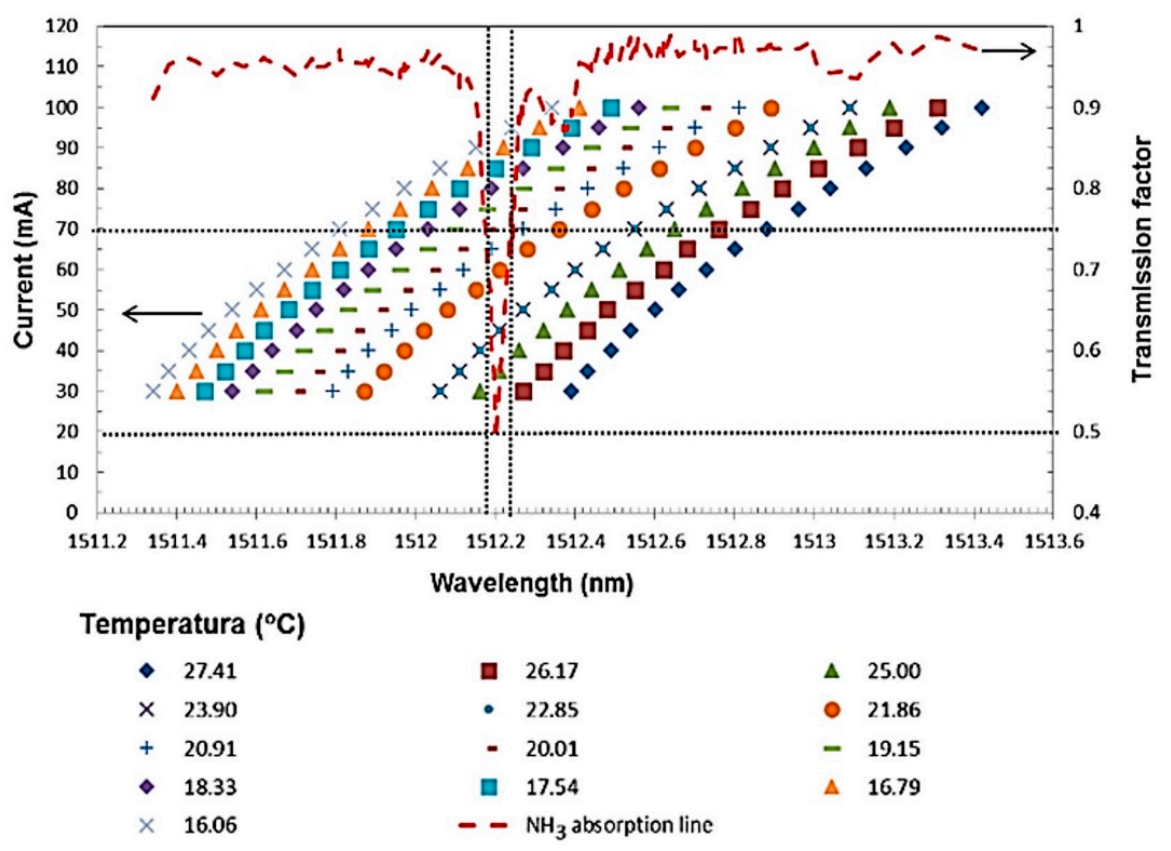

Figure 5. DFB laser emission wavelength shift in function of current, for a specific temperature, of the detected $\mathrm{NH}_{3}$ absorption line at $1512.21 \mathrm{~nm}$.

To lock the laser wavelength to the target gas absorption center line, the experimental setup had a feedback loop that consisted in part of the emitted light passing through the reference gas cell. This means that, on channel B of the lock-in amplifier (Figure 3), the amplitude of first harmonic must equal zero, thus tuning the laser wavelength to the targeted gas. The amplitude of the second harmonic (channel A of lock-in amplifier), which is proportional to the gas concentration, was normalized by the average laser intensity read by the photodetector. 
Real-time concentration measurement was performed for each gas $\left(\mathrm{NH}_{3}, \mathrm{CO}_{2}\right.$, and $\left.\mathrm{CH}_{4}\right)$ one at a time by introducing the gas inside the multi-pass cell and sealing it at room temperature and atmospheric pressure. The different gases' $\left(\mathrm{NH}_{3}, \mathrm{CO}_{2}\right.$, and $\left.\mathrm{CH}_{4}\right)$ concentrations were achieved by mixing a calibrated gas sample in an $\mathrm{N}_{2}$ environment. Figure 6 illustrates the results obtained.

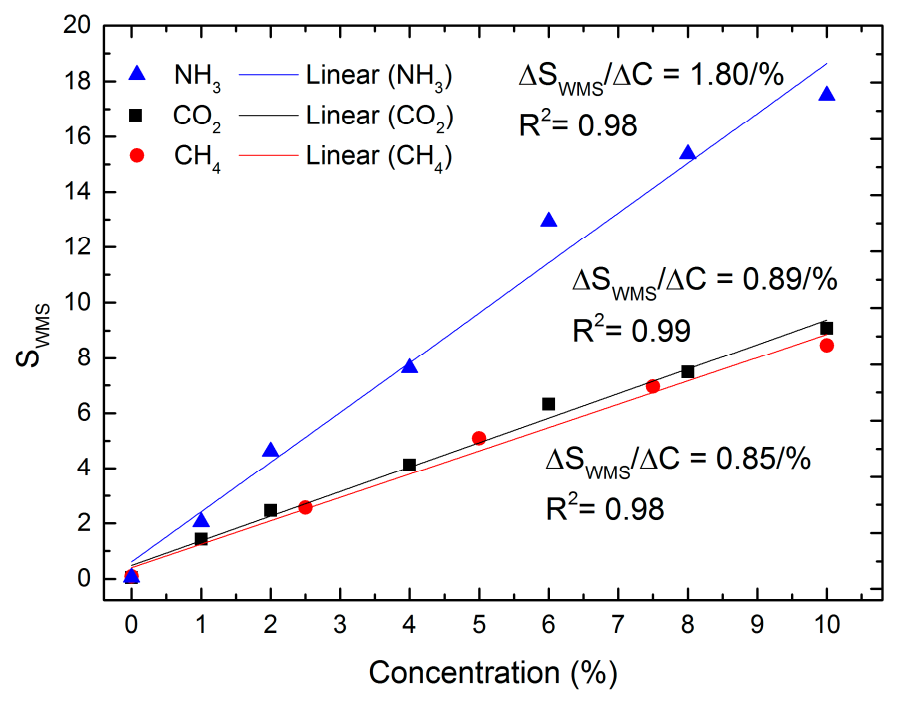

Figure 6. Output of the sensing system versus ammonia $\left(\mathrm{NH}_{3}\right)$, carbon dioxide $\left(\mathrm{CO}_{2}\right)$, and methane $\left(\mathrm{CH}_{4}\right)$ concentrations using the multi-pass cell of $160 \mathrm{~cm}$.

The proposed sensing system shows linear responses in the concentration range from 0 to $10 \%$, and has a limit of detection (LOD) of $0.06 \%, 0.04 \%$, and $0.09 \%$ for ammonia, carbon dioxide, and methane measurements, respectively. The limit of detection was defined according to [45]:

$$
L O D=\mu_{b}+K_{D} \frac{\sigma_{b}}{S_{S}}
$$

where $\mu_{b}$ and $\sigma_{b}$ are the mean and the standard deviation of the blank measures ( $0 \%$ of concentration), respectively, and $K_{D}$ a factor chosen according to the confidence level desired (it was chosen $K_{D}$ equal to 3 that corresponds to a confidence level of about $90 \%$ ). The sensitivity of the proposed system $S_{S}$ is the slope $\left(\Delta S_{W M S} / \Delta C\right)$ of the calibration curve, where $C$ is the gas concentration and $S_{W M S}$ is the normalized signal measured by the sensing system that is proportional to gas concentration. This signal ( $\mathrm{S}_{\mathrm{WMS}}$ ) was obtained through division of the lock-in amplifier signal by the photodetector signal. In this case, the sensitivities obtained were $1.80 \%, 0.89 \%$, and $0.85 \%$ for ammonia, carbon dioxide, and methane measurements, respectively.

\section{The ECOAL Project Implementation}

The S. Pedro da Cova self-burning coal waste pile was selected for the implementation of the ECOAL-MGT project due to the knowledge already obtained about the geological characteristics of the material that constitutes the coal waste pile, taking into account the research that has been carried out since 2010. The installation of the prototypes was done during the first semester of 2015.

\subsection{Field System Installation}

To support the prototype design, its installation, and the continuous measurement of temperature and gaseous emissions, the monitoring of temperature in a region of the surface of the coal waste pile (Figure 7A) was performed monthly since February 2013, using infrared thermography [7]. Figure 7B illustrates the thermographic image acquired in February 2015, where the main focus of the combustion process is identified. The results obtained from these prior monitoring temperature campaigns 
supported the prototype design and installation for continuous measurement of temperature and gas and contributed to the validation of the measurements performed with the fiber sensing technology.



Figure 7. (A) General view of the area under combustion where is visible the platforms along the slope and the gaseous emissions; (B) thermographic image used for preliminary temperature characterization of the region; (C) aerial view of S. Pedro da Cova coal waste pile (red contour), showing: (i) region of distributed temperature measurement cable with approximately $1300 \mathrm{~m}$ (yellow line); (ii) gas measurements spots (end of green lines); (iii) optical fiber cable path to the data collection station.

The geographical layout of the deployed fiber optic sensing system is illustrated in Figure 7C, while the general architecture of this system is shown in Figure 8. For distributed temperature measurement, Brillouin Optical Time-Domain Analysis (BOTDA) is proposed to monitor the waste pile, with a single-mode fiber layout extended over the whole area of the waste pile undergoing combustion.

The optical cable for distributed temperature measurement could not be a standard one considering the high temperatures. Therefore, a special optical cable fabricated by Brugg $(5 \mathrm{~mm}$ HDPE - high-density polyethylene incorporating a stainless steel tube) (Brugg Group, Switzerland) was used, permitting reliable operation up to $150{ }^{\circ} \mathrm{C}$, which can be extended up to $180-200{ }^{\circ} \mathrm{C}$ if the cable is installed without tension and with small curvature. The fibers were loose inside the cable and it was ensured that the cable thermal expansion did not affect the fibers. A length of $\sim 2600 \mathrm{~m}$ of cable was buried at 10-20 cm depth in platforms that were prepared in the pile slope with a $\sim 1 \mathrm{~m}$ width (a deeper burial would be risky considering the temperature resistance of the cable). It runs along an extension of $\sim 1300 \mathrm{~m}$ of the coal pile in the regions where the combustion process seemed to be more intense (Figures 1C and 7A; views of the installation process are shown in Figure 9A. At the end of such a region, a splice box permitted the cable to turn around, returning along the same physical path (which explains why the cable extension used double the measurement region length).

As two fibers are used in the measuring cable, redundant measurements are obtained in each position. The temperature estimation is, therefore, achieved by averaging the results obtained from 
the two independent measurements realized in the same position. The BOTDA architecture used in this case is essentially similar to the conventional systems described in the literature [46], except that the proposed system incorporates balanced detection [47]. Balanced detection provides substantial advantages in this case as it eliminates common-mode noise, provides an improved signal-to-noise ratio over the conventional single-detector systems, and offers a method of eliminating polarization noise in the BOTDA signal by employing orthogonal probe sidebands. It also delivers a better use of the dynamic range of the detector as it avoids saturation and allows higher input powers.

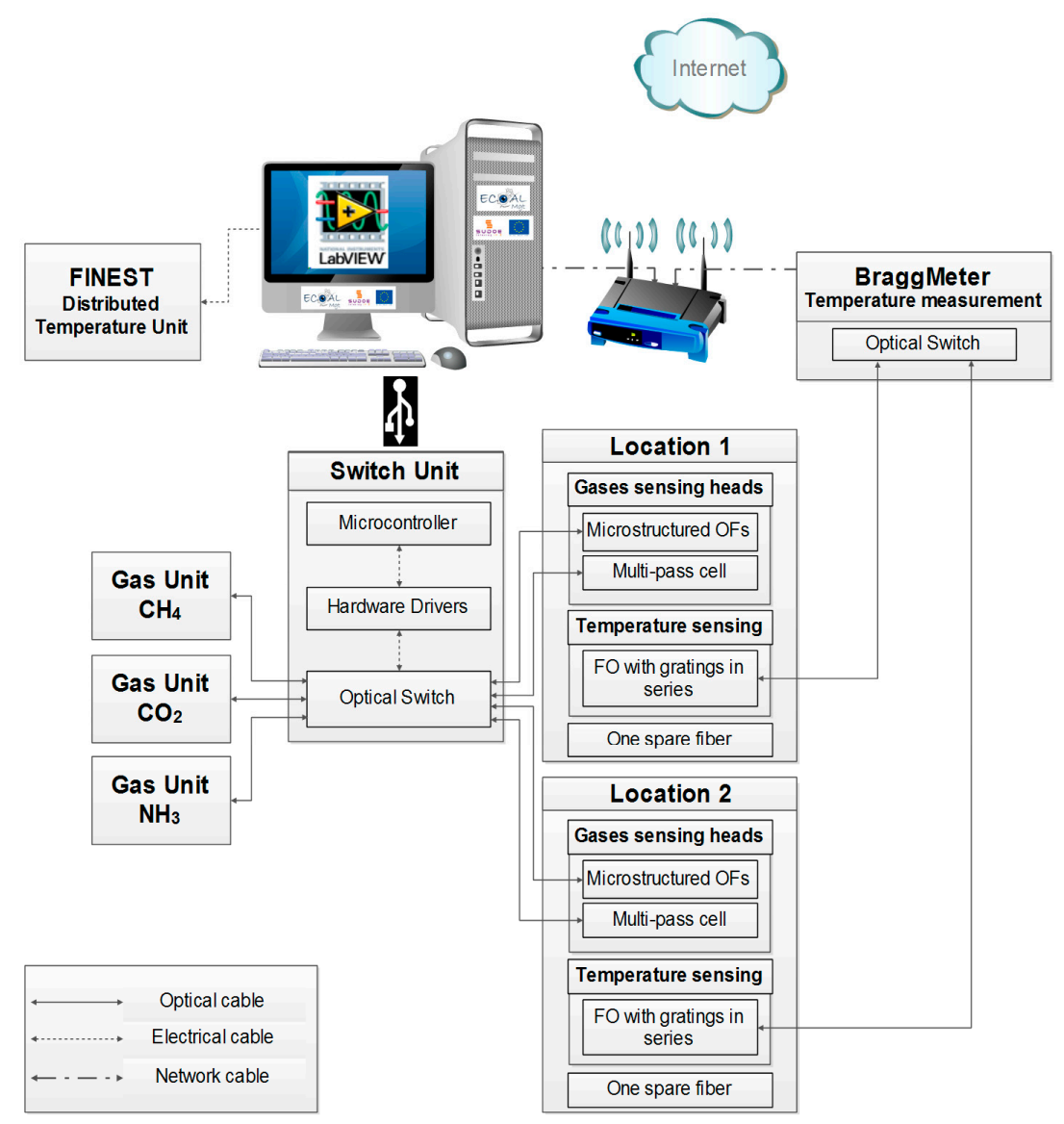

Figure 8. General architecture of the optical fiber sensing system for gas and temperature measurement in coal waste piles.

High spatial resolution measurements are performed using the differential pulse-width pair technique [48]. This technique overcomes the conventional time-frequency trade-offs encountered in traditional BOTDA by subtracting the gain profiles obtained in the same position with slightly different pulse lengths. A resolution of $0.5 \mathrm{~m}$ is thus obtained, subtracting the results obtained with 52 and 47 ns pulses.

For gas measurement, two different spots in the coal waste pile were selected (Figure 7C). In these spots metallic tube structures with a height of $\sim 1.6 \mathrm{~m}$ were installed to isolate the gas sensors from the nearby coal pile material (the structure permitted the gas emitted by this material to access its interior; views of these structures are shown in Figure 9B). In one of these spots (the left one in Figure 7C), besides gas sensing heads, a Fiber Bragg Grating (FBG)-based sensor system was installed with three temperature measurement points at different heights, the purpose being the characterization of the temperature profile of the metallic column aiming gas sensor calibration objectives. In this spot was also located a novel interferometric temperature sensor based on microstructured optical fibers to assess its performance in such a harsh environment. 


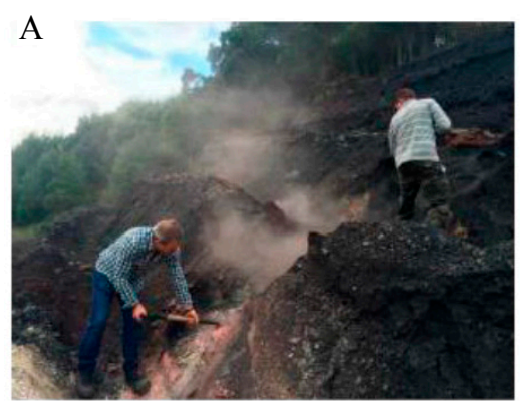

B

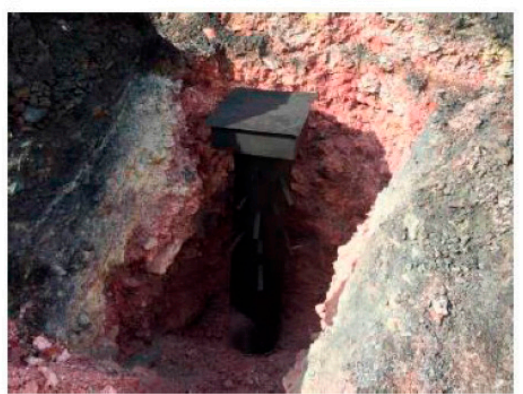

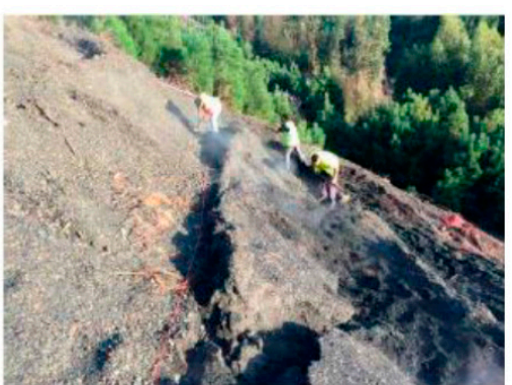

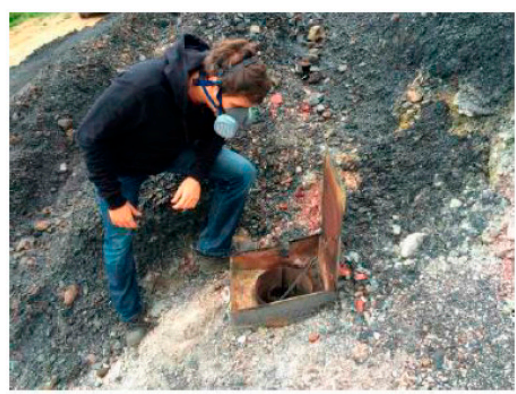

Figure 9. (A) View of the field installation of the fiber optic temperature cable; (B) one of the structures where the gas sensors/point temperature sensors were installed.

\subsection{Results}

\subsubsection{Temperature Measurement}

A comprehensive set of temperature measurements in the coal waste pile was gathered over several weeks. Figure 10A depicts a measurement of the temperature profile for the complete fiber length at a given moment of the day on 28 February 2015. Each point is measured twice, obtaining a symmetrical profile but also measurement redundancy. The temperature data are easily extracted from the measured BFS by using the sensitivity of the BFS to temperature. Figure 10B shows the temperature profile of $250 \mathrm{~m}$ of fiber length obtained during one week, for which two measurements were acquired consecutively in the same day. The two profiles obtained during the same day (the orange and gray lines in Figure 10B) show good agreement between them, highlighting the repeatability of the BOTDA system. The other temperature profile (blue line) was performed a week before the others. As can be seen, some temperature peaks present in the blue line do not appear in the orange and gray lines.
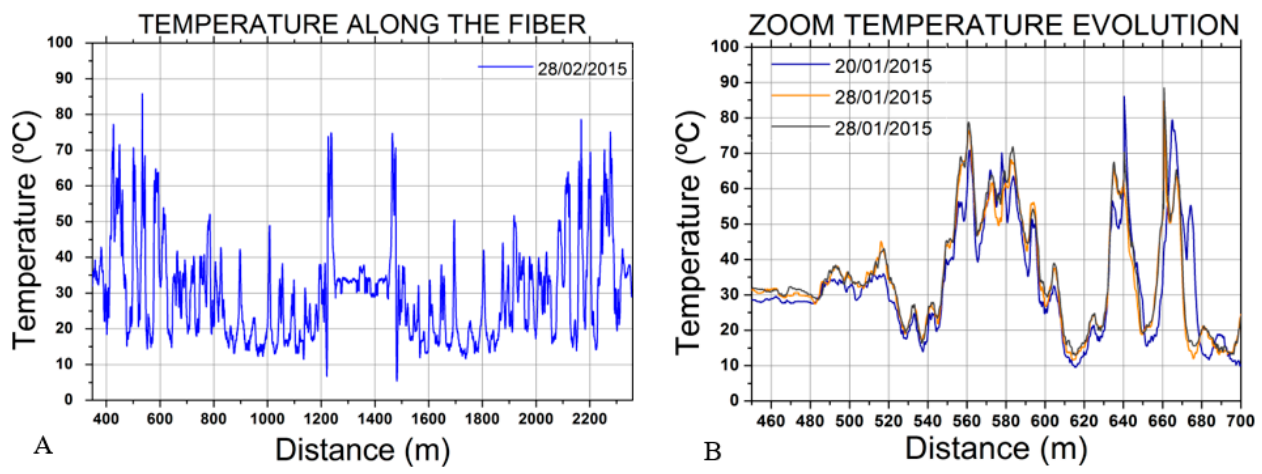

Figure 10. (A) Temperature profile along the optical fiber in the coal pile, in the normal route of the cable and in the return route; (B) details of the one-week evolution of the temperature profile along the optical fiber in the coal pile. 
The burning pattern of the coal waste pile is a dynamic process, quite often changing with time in a non-foreseeable way. This happened with the temperature level in one of the spots for gas sensing (the right one in Figure 7C), which increased to a value of $270{ }^{\circ} \mathrm{C}$ (Figure 11A) not compatible with the operation of the gas sensors. Therefore, at this stage the activity was focused on the other spot, which shows a much lower temperature, as seen in Figure 11B, where the temperature measured by the FBG system is shown at three points, located at depths of $1.3,1.4$, and $1.5 \mathrm{~m}$, over approximately 10 days (from 25 February to 5 March 2015). Even at a reduced scale, the dynamics of the burning coal pile is also imprinted on this data, with a temperature amplitude variation of $\sim 18{ }^{\circ} \mathrm{C}$ observed in the period considered. The figure also shows that a depth increase of $20 \mathrm{~cm}$ causes a temperature rise of $\sim 4{ }^{\circ} \mathrm{C}$.
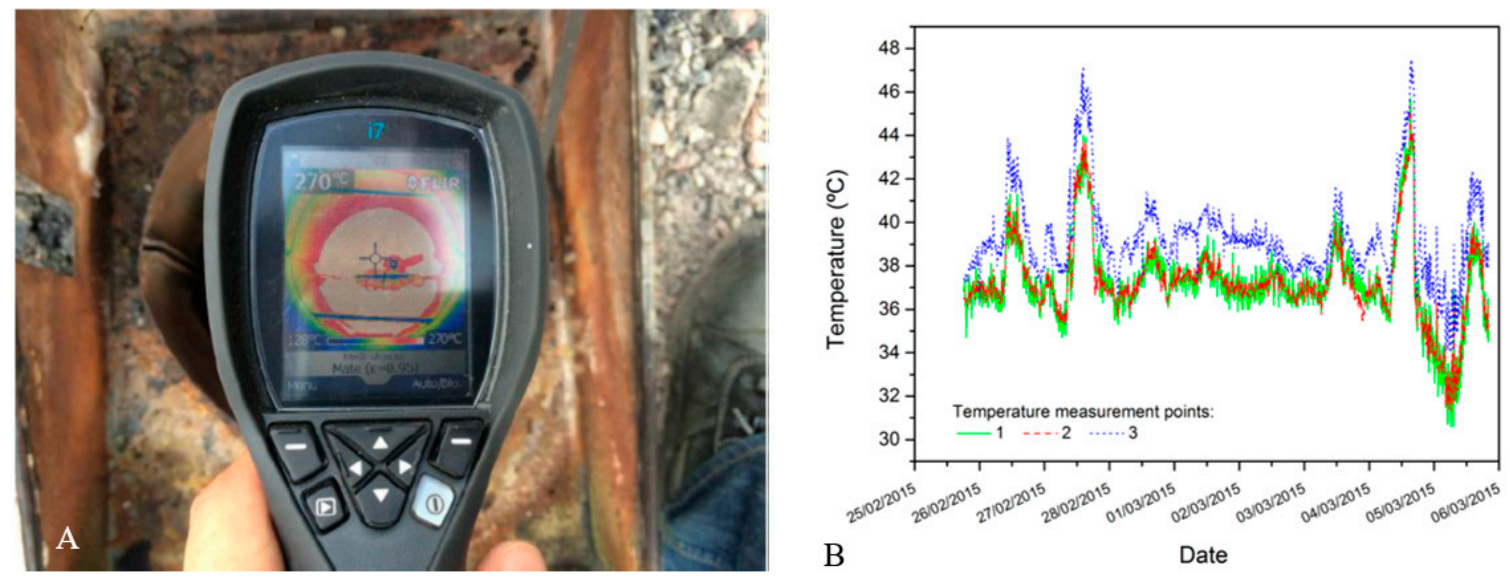

Figure 11. (A) Thermographic temperature measurement in one of the gas sensing spots; (B) temperature evolution in the other gas sensing spot at depths of $1.3 \mathrm{~m}(1), 1.4 \mathrm{~m}(2)$, and $1.5 \mathrm{~m}$ (3).

As mentioned at the end of Section 4.1, a hybrid low-finesse Fabry-Pérot interferometer was developed for temperature sensing, based on a four-bridge double-Y-shape-core microstructured fiber, designed within the consortium (Figure 12A).

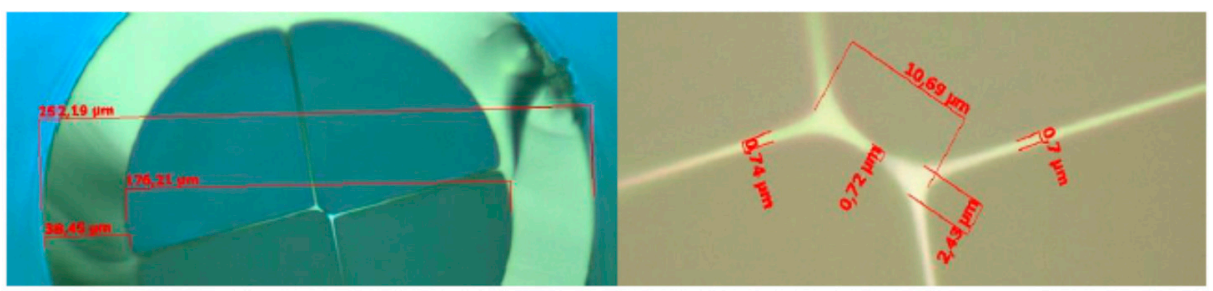

(A)

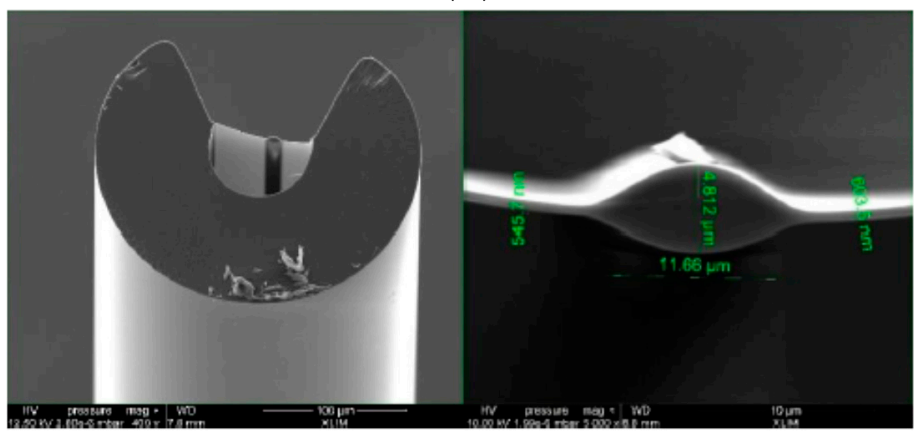

(B)

Figure 12. Views of the cross section of the fibers projected for temperature (A) and gas sensing (B). 
The sensing head was protected by a ceramic capillary cap with an inner diameter of $\sim 127 \mu \mathrm{m}$ in order to prevent any damage during the installation process. Several tests were made in the laboratory before installation, verifying the performance of the temperature MOF-PF sensor with this cap. The cap did not influence the sensor's sensitivity or time response to temperature variations.

The interrogation of the FP sensor was performed using a commercial FBG interrogator (Smartec SM125, SMARTEC, Lugano, Switzerland), with MatLab software enabling the use of FFT remote real-time (scan frequency of $1 \mathrm{~Hz}$ ) analysis. By monitoring the phase of the FFT, temperature variations are characterized without the negative influence of noise or amplitude fluctuations [49]. The MOF-FP optical spectrum and its FFT (magnitude) are shown in Figure 13.
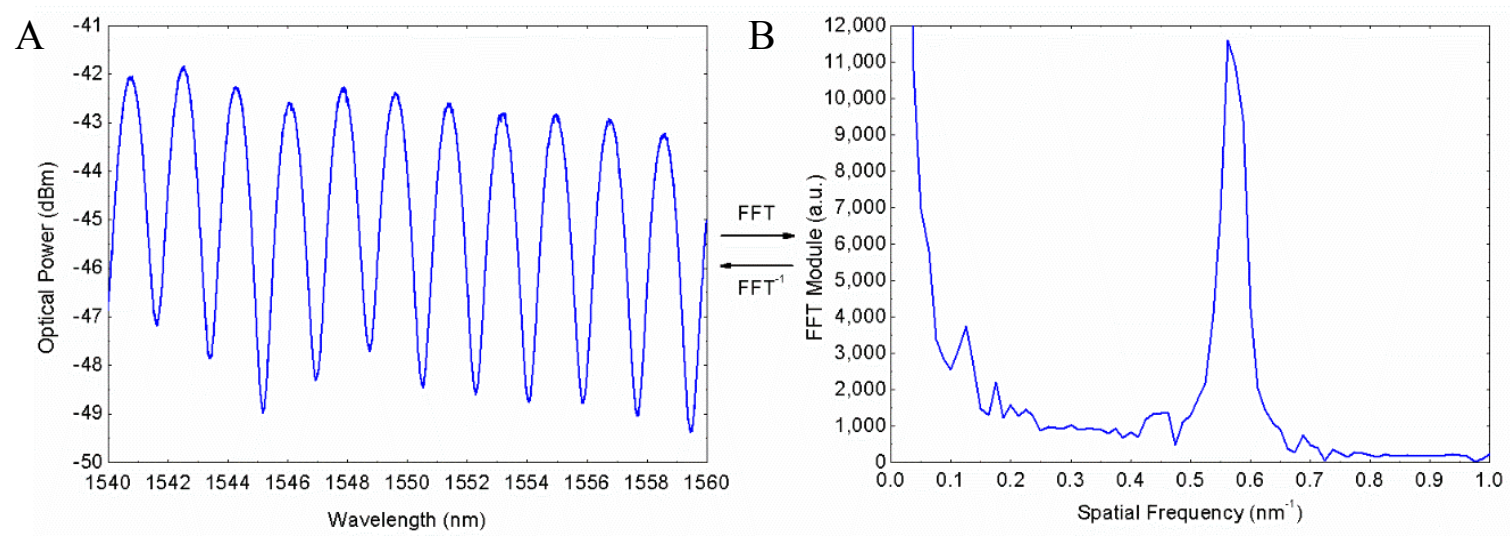

Figure 13. (A) Optical spectrum of the MOF-FP sensor and (B) its FFT.

This technique allows us to multiplex simultaneously in a single channel several sensors (the authors have used up to five successfully), thereby reducing the economic cost of the system.

In order to reference the temperature close to the surface of the measuring spot, the MOF-FP sensor was installed at a depth of $\sim 15 \mathrm{~cm}$. Finally, the thermographic camera was employed to set the initial reference of the sensor and verify the correct operation of the optical device.

Using one of these structures, real-time temperature measurement was performed in the left gas spot indicated in Figure 7C (from 18 June to 22 June 2015; a period different from that considered in the context of Figure 10B). Figure 14 shows the results obtained (a commercial FBGs interrogator and the FFT technique [49] were applied to interrogate the sensor). Daily temperature variation is visible, as well as the change of the average temperature along this period associated with small changes in the burning dynamics of the coal waste pile.
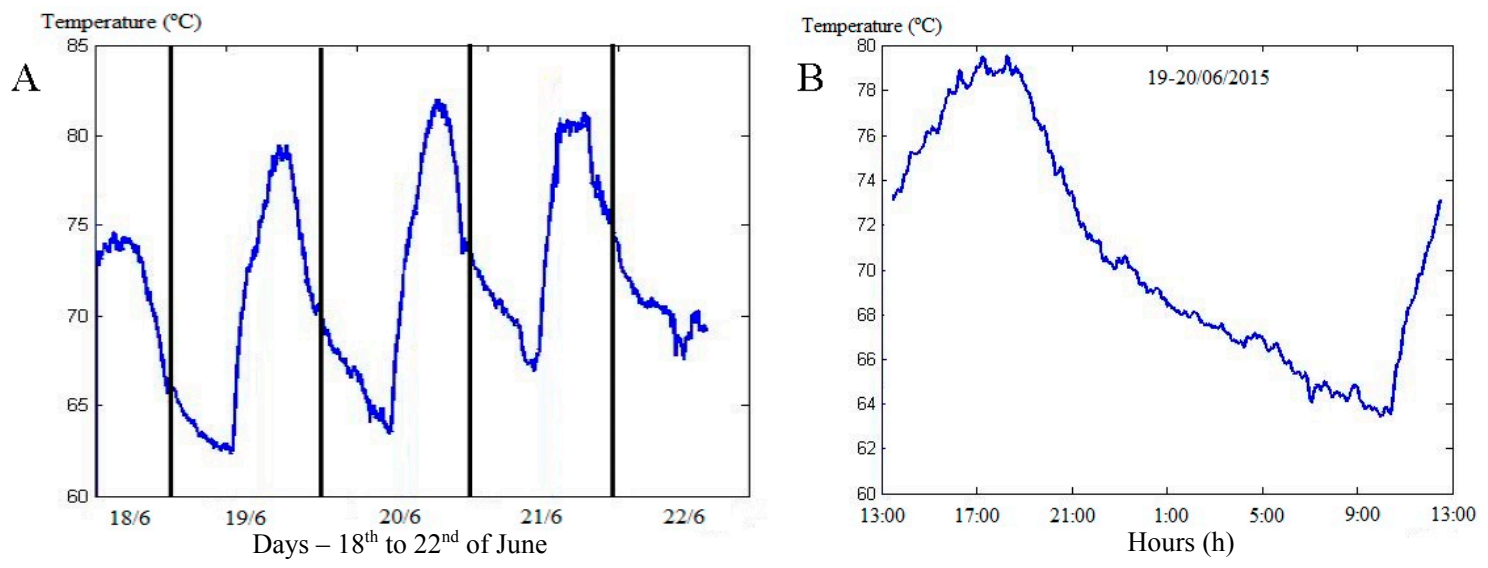

Figure 14. (A) Change in temperature over five days in the left gas spot of Figure 7C; (B) details of variation over $24 \mathrm{~h}(19 / 20$ June 2015). 


\subsubsection{Gaseous Emissions}

The monitoring of gas emissions was performed on the gas sensing spot with lower temperature (the left one in Figure 7C). As shown in Figure 11B, rapid bursts of high temperature were observed in this spot, which are presumably associated with the spontaneous release of hot gas at certain positions of the pile. These outcomes can be very helpful in the development of geological models of pile evolution.

At this gas measurement spot, residual emission of methane and carbon dioxide was found in the period 12-17 March 2015 (illumination with a DBF laser emitting at $1653.72 \mathrm{~nm}$ and $1572.0 \mathrm{~nm}$, respectively). The same did not happen concerning ammonia, with detection associated with the light emitted by a DFB laser that works at a wavelength of $1512.21 \mathrm{~nm}$, guided to the multi-pass cell sensing head with $160 \mathrm{~cm}$ of optical path length. As shown in Figure 15A, ammonia concentration (volume) has a strong daily variation, in some periods of the day reaching $0.6 \%-0.7 \%$, decreasing in some others to residual values (a zoom for one-day evolution is shown in Figure 15B). A longer series of data is required to identify the main features of this behavior and determine the cause.
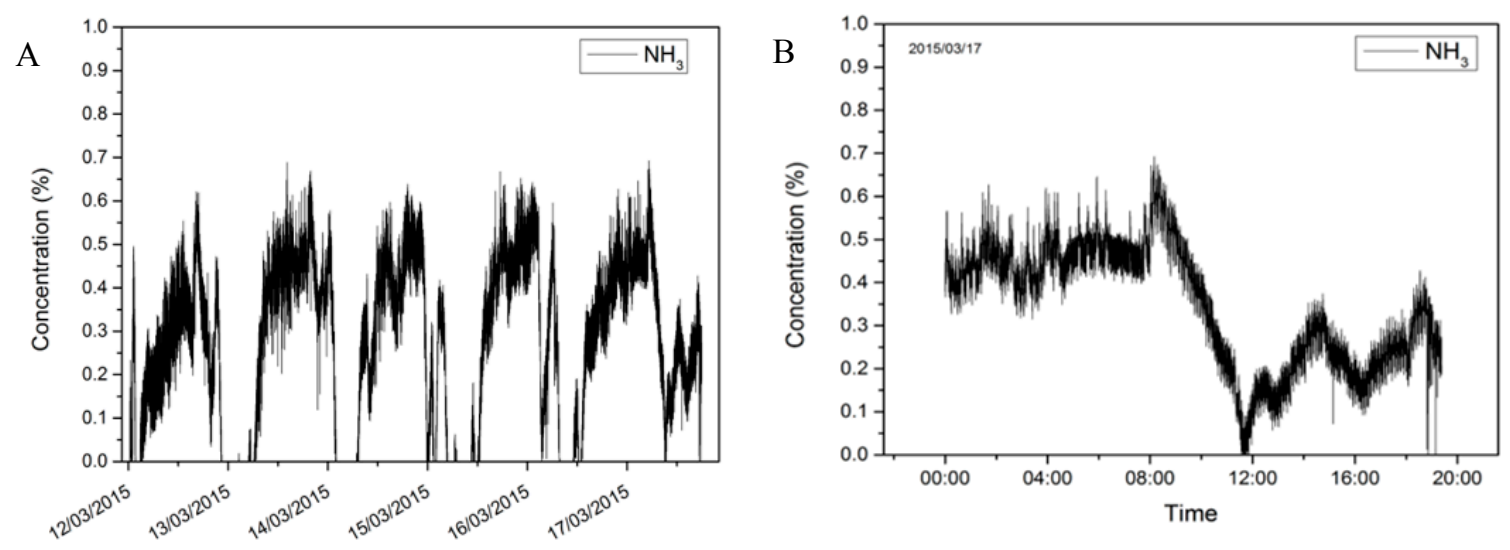

Figure 15. (A) Change in ammonia concentration over five days in the left gas spot of Figure 7C; (B) details of variation over one day (17 March 2015).

In the architecture of the gas sensing system shown in Figure 4, a parallel approach for gas detection based on the utilization of microstructured optical fibers is indicated, with design adjusted for the conditions in which the sensing heads operate. Within the consortium activity, several fibers were projected, fabricated, and characterized in the lab; one example is shown in Figure 12B. However, the field tests performed indicated that the small size of the hole through which the gas flows and the short optical path length for the interaction between the gas and light is not enough to measure the target gases with accuracy. Further research in this field is necessary.

\subsection{The GIS Open-Source Desktop Application for Monitoring the Combustion Process}

In order to monitor the temperature variations in the S. Pedro da Cova self-burning coal waste pile, a GIS desktop application named GIS-ECOAL was developed in a GIS open-source environment to produce dynamic temperature maps [9]. The main focus of this step was the creation of an application with a user-friendly graphic interface that automatically generates several interpolation maps with the temperature records. Also, a video composed of a sequence of individual maps, allowing for the evaluation of the temperature dynamics in a specific area, was generated. The interpolation maps were based on the kriging method as it provides optimal interpolation estimation for a given coordinate location, as well as variance estimation for the interpolation value. The video was created in webm format, and could be displayed by any video player program. The application also provided the possibility of direct video visualization in the application graphic interface. Moreover, the application has another functionality: evaluating the temperature dynamic of a specific point in the field, through a 
graphic representation of the temperature values as a function of time, complemented by a report with maximum and minimum temperature information and a table with a statistical analysis for each day. The table is created in text format, with statistical variables related to each day, such as average, median value, maximum and minimum temperature, standard deviation, coefficient of variation, and amplitude.

Valuable information about the variation in temperature at different moments of a day and the distribution and dispersion of the combustion activity and intensity in the fire area could be obtained from the analysis of the individual maps, since the combustion process in the coal waste pile was spatially very heterogeneous. For instance, one main area of more intense combustion was recognized, the large red part at the bottom of the monitored area (Figure 16), and the identification of significantly higher temperatures in the left and upper corner of the waste pile (more yellowish areas) indicated that the combustion activity may be increasing in this area. The identification of this new focus of combustion was only possible through the maps and video analysis created by the GIS-ECOAL application. The plot functionality was also tested with three points and the analysis demonstrated that temperatures at point 1 , which is located in an area with intense combustion activity, are higher than $90{ }^{\circ} \mathrm{C}$ while, at point 2 , the temperatures vary between $50{ }^{\circ} \mathrm{C}$ and $60^{\circ} \mathrm{C}$ and, at point 3 , are generally between $40{ }^{\circ} \mathrm{C}$ and $50{ }^{\circ} \mathrm{C}$.

\section{5-07-11 18h05}

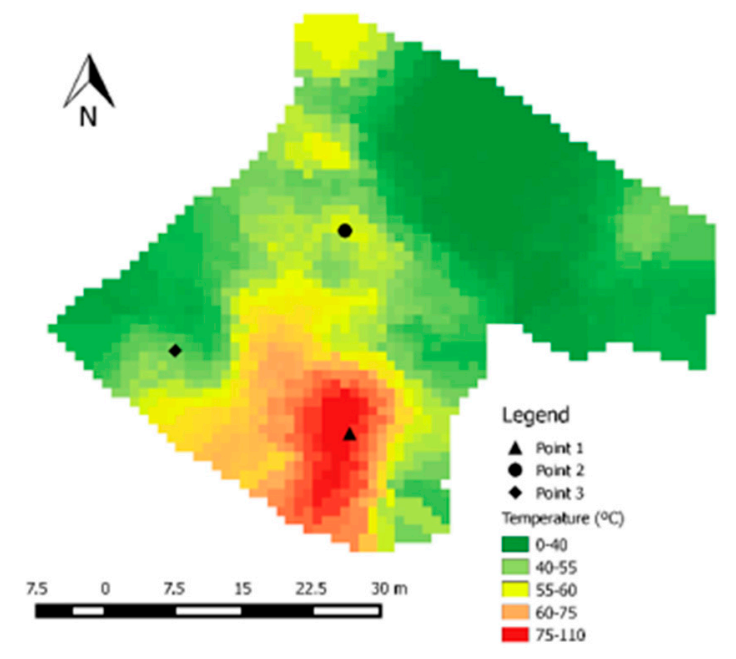

Figure 16. Temperature mapping of the coal waste pile.

The identification of the temperatures associated with the combustion process and the main and/or new focus of the combustion activity could be estimated from the maps generated. The video analysis allowed for the dynamic and continuous visualization of the combustion process in the monitored area, contributing to the prediction of evolution scenarios and helping to establish mitigation measures and appropriate management practices.

\section{Conclusions}

A central issue when dealing with coal waste piles in combustion is to identify, as best as possible, their dynamics, looking for the forecast of their time and spatial evolution, therefore enabling us to program and implement corrective and/or preventive actions to minimize the hazards these structures may pose to human communities and the environment. Consequently, the geological modeling of these coal piles is an inestimable tool, which, however, only works if fed proper data. The gathering of proper data is not trivial in view of the conditions a sensing system has to withstand. The optical fiber sensing system outlined here, with components of gas emission monitoring, point temperature 
measurement, and distributed temperature measurement, as well as the build-up of tools to produce dynamic temperature maps and videos representing the spatial and temporal variation of temperature in a GIS open-source environment, was developed with the aim of proving that this technology can achieve the real-time assessment of the conditions of coal waste piles, and therefore has the potential to be applicable in a huge number of these structures distributed all around the world.

Acknowledgments: This work was supported by the project ECOAL-MGT-SOE3/P2/P714, Ecological Management of Coal Waste Piles in Combustion, SUDOE-Interreg IV B. The author Joana Ribeiro benefited from a post-doctoral scholarship financed by the Portuguese Science and Technology Foundation, FCT (Ref: SFRH/BPD/76230/2011). The authors acknowledge the funding provided by the Institute of Earth Sciences under contracts UID/GEO/04683/2013 with FCT and COMPETE POCI-01-0145-FEDER, and also by the Spanish Ministry of Economy via project TEC2013-47264-C2-2-R. The work of Sonia Martín-Lopez was supported by the Spanish Ministry of Science and Innovation through a "Ramón y Cajal" Contract. Miguel González Herráez acknowledges the support of the European Research Council through Starting Grant U-FINE (Grant No. 307441).

\section{Author Contributions:}

Joana Ribeiro: Sensing system design; characterization of geological materials that constitute the coal waste pile; thermographic measurements;

Duarte Viveiros: Sensing system design, gas and temperature point sensors;

João Ferreira: Sensing system design, gas and temperature point sensors;

Alexia Lopez-Gil: Distributed temperature sensing;

Alejandro Dominguez-Lopez: Distributed temperature sensing;

Hugo F. Martins: Distributed temperature sensing;

Rosa Perez-Herrera: Sensor multiplexing and point temperature sensing;

Aitor Lopez-Aldaba: Sensor multiplexing and point temperature sensing;

Lia Duarte: Development of the open source GIS application;

Ana Pinto: Sensor multiplexing and point temperature sensing;

Sonia Martin-Lopez: Distributed temperature sensing;

Hardy Baierl: Project, fabrication and characterization of microstructured optical fibers;

Raphael Jamier: Project, fabrication and characterization of microstructured optical fibers;

Sébastien Rougier: Project, fabrication and characterization of microstructured optical fibers;

Jean-Louis Auguste: Project, fabrication and characterization of microstructured optical fibers;

Ana Cláudia Teodoro: Development of the open source GIS application;

José Alberto Gonçalves: Development of the open source GIS application;

Oscar Esteban: Distributed temperature sensing;

José Luís Santos: Sensing system design, gas and temperature point sensors;

Philippe Roy: Sensing system design; project, fabrication and characterization of microstructured optical fibers;

Manuel Lopez-Amo: Sensing system design; sensor multiplexing and point temperature sensing;

Miguel Gonzalez-Herraez: Sensing system design and distributed temperature sensing;

José Manuel Baptista: Sensing system design; gas/temperature point sensing;

Deolinda Flores: Sensing system design; characterization of geological materials that constitute the coal waste pile.

Conflicts of Interest: The authors declare no conflict of interest.

\section{References}

1. Zhang, Y.; Yang, W.; Han, D.; Kim, Y.I. An Integrated Environment Monitoring System for Underground Coal Mines, Wireless Sensor Network Subsystem with the Multi-parameter Monitoring. Sensors 2014, 14, 13149-13170. [CrossRef] [PubMed]

2. Aminossadati, S.M.; Amanzadeh, M.; Kizil, M.S.; Liu, T. Development and Utilization of Fibre Optic-based Monitoring Systems for Underground Coal Mines. In Proceedings of the 14th Coal Operators' Conference, Wollongong, Australia, 12-14 February 2014; University of Wollongong: Wollongong, Australia, 2014; pp. 369-380.

3. Viveiros, D.; Ribeiro, J.; Carvalho, J.P.; Ferreira, J.; Pinto, A.M.R.; Perez-Herrera, R.A.; Diaz, S.; Lopez-Gil, A.; Dominguez-Lopez, A.; Esteban, O.; et al. Fiber optic sensing system for monitoring of coal waste piles in combustion. In Proceedings of the 23rd International Conference on Optical Fibre Sensors, Santander, Spain, 2-6 June 2014; Volume 915730, p. 4. [CrossRef] 
4. Viveiros, D.; Ribeiro, J.; Ferreira, J.; Lopez-Aldaba, A.; Pinto, A.M.R.; Perez-Herrera, R.A.; Diaz, S.; Lopez-Gil, A.; Dominguez-Lopez, A.; Esteban, O.; et al. Fiber Optic Sensing System for Temperature and Gas Monitoring in Coal Waste Pile Combustion Environments. In Proceedings of the 24th International Conference on Optical Fibre Sensors, Curitiba, Brazil, 28 September-2 October 2015; Volume 96343Y-2, p. 4. [CrossRef]

5. Viveiros, D.; Ferreira, J.; Silva, S.; Ribeiro, J.; Flores, D.; Santos, J.L.; Frazão, O.; Baptista, J.M. Wavelength Modulation Spectroscopy for Ammonia Sensing. In Proceedings of the 1st Doctoral Congress in Engineering, Porto, Portugal, June 2015; pp. 3-5.

6. Viveiros, D.; Ferreira, J.; Silva, S.O.; Ribeiro, J.; Flores, D.; Santos, J.L.; Frazão, O.; Baptista, J.M. Ammonia Sensing System Based on Wavelength Modulation Spectroscopy. Photonic Sens. 2015, 5, 109-115. [CrossRef]

7. Ribeiro, J.; Viveiros, D.; Ferreira, J.; Santos, J.L.; Baptista, J.M.; Flores, D. Monitorização ambiental de escombreira de S. Pedro da Cova: Temperatura de combustão. Comun. Geol. 2014, 101, 1063-1065.

8. Ribeiro, J.; Viveiros, D.; Ferreira, J.; Suárez-Ruiz, I.; Santos, J.L.; Baptista, J.M.; Flores, D. Volatile organic compounds emitted from self-burning coal waste piles in Spain and Portugal: Environment and human health concerns. In Progress in Medical Geology; Ibaraki, M., Mori, H., Eds.; Cambridge Scholars Publishing: Newcastle upon Tyne, UK, 2017; pp. 229-247. ISBN 978-1-4438-7319-2.

9. Duarte, L.; Teodoro, A.C.; Gonçalves, J.A.; Ribeiro, J.; Flores, D.; Lopez-Gil, A.; Dominguez-Lopez, A.; Angulo-Vinuesa, X.; Martin-Lopez, S.; Gonzalez-Herraez, M. Distributed temperature measurement in a self-burning coal waste pile through a GIS open source desktop application. Int. J. Geo-Inf. 2017, 6, 87. [CrossRef]

10. Suárez-Ruiz, I.; Crelling, J.C. (Eds.) Applied Coal Petrology: The Role of Petrology in Coal Utilization; Elsevier: Amsterdam, The Netherlands, 2008.

11. Younger, P.L. Environmental impacts of coal mining and associated wastes: A geochemical perspective. In Energy, Waste and the Environment: A Geochemical Perspective; Special Publications; Gieré, R., Stille, P., Eds.; Geological Society: London, UK, 2004; Volume 236, pp. 169-209.

12. Stracher, G.B.; Taylor, T.P. Coal fires burning out of control around the world: Thermodynamic recipe for environmental catastrophe. Int. J. Coal Geol. 2004, 59, 7-17. [CrossRef]

13. Stracher, G.B. (Ed.) Geology of Coal Fires: Case Studies from around the World. Reviews in Engineering Geology XVIII; Geological Society of America: Boulder, CO, USA, 2007; 278p.

14. Stracher, G.B.; Prakash, A.; Sokol, E.V. (Eds.) Coal and Peat Fires: A Global Perspective; Elsevier: Amsterdam The Netherlands, 2011; Volume 1: Coal-Geology and Combustion; 380p.

15. Stracher, G.B.; Prakash, A.; Sokol, E.V. (Eds.) Coal and Peat Fires: A Global Perspective; Elsevier: Amsterdam, The Netherlands, 2013; Volume 2: Photographs and Multimedia Tours; 584p.

16. Stracher, G.B.; Prakash, A.; Sokol, E.V. (Eds.) Coal and Peat Fires: A Global Perspective; Elsevier: Amsterdam, The Netherlands, 2015; Volume 3: Case Studies-Coal Fires; 816p.

17. Ciesielczuk, J.; Misz-Kennan, M.; Hower, J.C.; Fabiańska, M.J. Mineralogy and geochemistry of coal wastes from the Starzykowiec coal-waste dump (Upper Silesia, Poland). Int. J. Coal Geol. 2014, 127, 42-55. [CrossRef]

18. Gürdal, G.; Hoşgörmez, H.; Özcan, D.; Li, X.; Liu, H.; Song, W. The properties of Çan Basin coals (Çanakkale-Turkey): Spontaneous combustion and combustion byproducts. Int. J. Coal Geol. 2015, 138, 1-15. [CrossRef]

19. Misz, M.; Fabiańska, M.; Cmiel, S. Organic components in thermally altered coal waste: Preliminary petrographic and geochemical investigations. Int. J. Coal Geol. 2007, 71, 406-424. [CrossRef]

20. Misz-Kennan, M.; Fabiańska, M. Thermal transformation of organic matter in coal waste from Rymer Cones (Upper Silesian Coal Basin, Poland). Int. J. Coal Geol. 2010, 81, 343-358. [CrossRef]

21. Misz-Kennan, M.; Fabiańska, M.J. Application of organic petrology and geochemistry to coal waste studies. Int. J. Coal Geol. 2011, 88, 1-23. [CrossRef]

22. Ribeiro, J.; Ferreira da Silva, E.; Flores, D. Burning of coal waste piles from Douro Coalfield (Portugal): Petrological, geochemical and mineralogical characterization. Int. J. Coal Geol. 2010, 81, 359-372. [CrossRef]

23. Ribeiro, J.; Flores, D.; Ward, C.; Silva, L.F.O. Identification of nanominerals and nanoparticles in burning coal waste piles from Portugal. Sci. Environ. 2010, 408, 6032-6041. [CrossRef] [PubMed]

24. Ribeiro, J.; Ferreira da Silva, E.; Pinto de Jesus, A.; Flores, D. Petrographic and geochemical characterization of coal waste piles from Douro Coalfield. Int. J. Coal Geol. 2011, 87, 226-236. [CrossRef] 
25. Ribeiro, J.; Silva, T.F.; Mendonça Filho, J.G.; Flores, D. Polycyclic aromatic hydrocarbons (PAHs) in burning and non-burning coal waste material. J. Hazard. Mater. 2012, 199-200, 105-110. [CrossRef] [PubMed]

26. Ribeiro, J.; Moura, R.; Flores, D.; Lopes, D.B.; Gouveia, C.; Mendonça, S.; Frazão, O. The Douro Coalfield Fires of Portugal. In Coal and Peat Fires: A Global Perspective; Stracher, G.B., Prakash, A., Sokol, E.V., Eds.; Elsevier: Amsterdam, The Netherlands, 2013; Volume 2: Coal-Fire Atlas of the World; pp. 313-337.

27. Ribeiro, J.; Suárez-Ruiz, I.; Ward, C.R.; Flores, D. Mineralogy of thermally altered coal mining residues in self-burning coal waste piles in Portugal and Spain. Comun. Geol. 2014, 101, 187-190.

28. Ribeiro, J.; Sant'Ovaia, H.; Gomes, C.; Ward, C.; Flores, D. Mineralogy and magnetic parameters of materials resulting from mining and consumption of coal from Douro Coalfield (NW Portugal). In Coal and Peat Fires: A Global Perspective; Stracher, G.B., Prakash, A., Sokol, E.V., Eds.; Elsevier: Amsterdam, The Netherlands, 2015; Volume 3: Case Studies-Coal Fires; pp. 493-507.

29. Ribeiro, J.; Suárez-Ruiz, I.; Flores, D. Geochemistry of self-burning coal mining residues from El Bierzo Coalfield (NW Spain): Environmental implications. Int. J. Coal Geol. 2016, 159, 155-168. [CrossRef]

30. Ribeiro, J.; Suárez-Ruiz, I.; Ward, C.R.; Flores, D. Petrography and mineralogy of self-burning coal wastes from anthracite mining in the El Bierzo Coalfield (NW Spain). Int. J. Coal Geol. 2016, 154-155, 92-106. [CrossRef]

31. Suárez-Ruiz, I.; Flores, D.; Mendonça Filho, J.G.; Hackley, P.C. Review and update of the applications of organic petrology: Part 2, Geological and Multidisciplinary Applications. Int. J. Coal Geol. 2012, 98, 73-94. [CrossRef]

32. Bell, F.G.; Bullock, S.E.T.; Halbich, T.F.J.; Lindsay, P. Environmental impacts associated with an abandoned mine in the Witbank Coalfield, South Africa. Int. J. Coal Geol. 2001, 45, 195-216. [CrossRef]

33. Finkelman, R.B. Potential health impacts of burning coal beds and waste banks. Int. J. Coal Geol. 2004, 51, 19-24. [CrossRef]

34. Pone, J.D.N.; Hein, K.A.A.; Stracher, G.B.; Annegarn, H.J.; Finkelman, R.B.; Blake, D.R.; McCormack, J.K.; Schroeder, P. The spontaneous combustion of coal and its byproducts in the Witbank and Sasolburg coalfields of South Africa. Int. J. Coal Geol. 2007, 72, 124-140. [CrossRef]

35. Querol, X.; Izquierdo, M.; Monfort, E.; Alvarez, E.; Font, O.; Moreno, T.; Alastuey, A.; Zhuang, X.; Lu, W.; Wang, Y. Environmental characterization of burnt coal gangue banks at Yangquan, Shanxi Province, China. Int. J. Coal Geol. 2008, 75, 93-104. [CrossRef]

36. Pinto de Jesus, A. Evolução sedimentar e tectónica da Bacia Carbonífera do Douro (Estefaniano C inferior, NW de Portugal. Cadernos Laboratorio Xeolóxico de Laxe Revista de Xeoloxía Galega e do Hercínico Peninsular 2003, 28, 107-125.

37. International Organization for Standardization 11760. Classification of Coals, 1st ed.; International Organization for Standardization: Geneva, Switzerland, 2005; 9p.

38. Custódio, J. Museu do Carvão E das Minas do Pejão; Programa Museológico; Câmara Municipal de Castelo de Paiva: Castelo de Paiva, Portugal, 2004; 87p.

39. Zhan, Y.; Wu, H.; Yang, Q.; Xiang, S.; He, H. Fiber grating sensors for high-temperature measurement. Opt. Lasers Eng. 2004, 46, 349-354. [CrossRef]

40. Lopez-Aldaba, A.; Pinto, A.M.R.; Lopez-Amo, M.; Frazão, O.; Santos, J.L.; Baptista, J.M.; Baierl, H.; Auguste, J.L.; Jamier, R.; Roy, P. Experimental and Numerical Characterization of a Hybrid Fabry-Pérot Cavity for Temperature Sensing. Sensors 2015, 15, 8042-8053. [CrossRef] [PubMed]

41. Bao, X.; Chen, L. Recent Progress in Distributed Fiber Optic Sensors. Sensors 2012, 12, 8601-8639. [CrossRef] [PubMed]

42. Angulo-Vinuesa, X.; Kartín-Lopez, S.; Corredera, P.; González-Herráez, M. Raman-assisted Brillouin optical time-domain analysis with sub-meter resolution over $100 \mathrm{~km}$. Opt. Express 2012, 20, 12147-12154. [CrossRef] [PubMed]

43. Ingle, J.D.; Crouch, S.R. Spectrochemical Analysis; Prentice Hall: London, UK, 1988; 609p.

44. Schilt, S.; Thévenaz, L.; Robert, P. Wavelength Modulation Spectroscopy: Combined Frequency and Intensity Laser Modulation. Appl. Opt. 2003, 42, 6728-6738. [CrossRef] [PubMed]

45. Thomsen, V.; Schatzlein, D.; Mercuro, D. Limits of detection in spectroscopy. Spectroscopy 2003, 18, 112-114.

46. Niklès, M.; Thévenaz, L.; Robert, P.A. Simple distributed fiber sensor based on Brillouin gain spectrum analysis. IEEE J. Lightwave Technol. 1997, 15, 1842-1851. 
47. Domínguez-López, A.; López-Gil, A.; Martín-López, S.; Gonzalez-Herraez, M. Signal-to-noise ratio improvement in BOTDA using balanced detection. IEEE Photonics Technol. 2014, 26, 338-341. [CrossRef]

48. Li, W.; Bao, X.; Li, Y.; Chen, L. Differential pulse-width pair BOTDA for high spatial resolution sensing. Opt. Express 2008, 16, 21616-21625. [CrossRef] [PubMed]

49. Leandro, D.; Mikel Bravo, M.; Ortigosa, A.; Lopez-Amo, M. Real-time FFT Analysis for Interferometric Sensors Multiplexing. J. Lightwave Technol. 2015, 33, 354-360. 